\title{
The Impact of Corporate Governance Mechanism, Company Characteristics on the Timeliness of Financial Statements: Evidence from Listed Companies in Vietnam
}

\author{
Phuong Lien Thi Hoang ${ }^{1}$ \\ Dong Xuan Pham ${ }^{1}$ \\ Eleftherios I. Thalassinos ${ }^{2}$ \\ Hoang Anh $\mathrm{Le}^{3}$ \\ ${ }^{1}$ Ho Chi Minh City University of Food Industry, \\ No. 140 Le Trong Tan Street, Tay Thanh Ward, \\ Tan Phu District, Ho Chi Minh City 7ooooo, \\ Vietnam \\ ${ }^{2}$ Department of Maritime Studies, \\ University of Piraeus, Karaoli and Dimitriou 8o, \\ Pireas 185 34, Greece \\ ${ }^{3}$ Banking University HCMC, No. 36 Ton That Dam Street, \\ Nguyen Thai Binh Ward, District 1, \\ Ho Chi Minh City 70oooo, \\ Vietnam
}

DOI: https://doi.org/10.36941/ajis-2022-0049

\section{Abstract}

This study aims to determine the factors affecting the timeliness of financial statements from the perspective of company characteristics and corporate governance mechanism. We examined the panel data from financial statements and annual reports of 172 Vietnamese companies listed on HOSE and HNX from 2014 to 2020 and found that company size had a negative impact on the timeliness of financial statements, while profitability had a positive impact. Besides, the findings also showed that board ownership and audit quality had a negative impact on the timeliness of financial statements. Our findings were derived from Bayesian analysis, which was first used in studies related to the timeliness of financial statements. On the basis of our findings, we offer several governance implications for stakeholders.

Keywords: Timeliness of Financial Statements, Corporate Governance Mechanism, Bayesian Analysis

\section{Introduction}

The stock market in the globe, and Vietnam in particular, has been improving in recent years. This fact demonstrates that the stock market's structure is becoming increasingly comprehensive, expanding in size and reaffirming its function as an efficient channel for capital transmission in the 
economy (Anh et al., 2019). However, the strong and positive development of the stock market poses many challenges for companies to separate ownership and management rights. Conflicts of interest between owners and management are unavoidable in the majority of joint-stock companies. According to delegate theory and asymmetric information theory, managers are informed of the company's financial and business situation, but the owners or shareholders are not. For these shareholders, audited financial statements are the sole credible source of information disclosed in the capital markets (Leventis et al., 2005), and when issued timely, financial statements assure their usefulness to those who require them (Givoly \& Palmon, 1982). As a result, the quality and timeliness of financial statement information will help investors boost their confidence and ensure rapid access to information that will assist them in making timely and successful investment decisions. Timeliness is an important informational attribute of financial statements (Carslaw \& Kaplan, 1991), and delays in the issuance of financial statements will increase uncertainty regarding investment decisions (Ashton et al., 1987). The negative impact of untimely financial reporting has become a concern in both developed and developing countries. This concern mainly stems from the risk of financial reporting time lag on financial reporting quality.

In Vietnam, the legal framework governing information disclosure has always been focused on perfecting since the stock market was formed. However, there are still some shortcomings in the disclosure of information on Vietnam's stock market, which reduces the transparency and publicity of financial information. In particular, the delay in disclosing financial statement information is a fairly common violation of public companies and securities trading organizations. Therefore, understanding the factors that determine the timeliness of financial statements will help guide capital market management policy (Owusu-Ansah, 200o), enhance decision-making, and reduce information asymmetry. Besides, enterprises' sense of self-discipline and sense of responsibility in the timely disclosure of financial statements is not high, leading to low information quality. It can be said that the above issues have posed the requirement to promptly publish audited financial statements to ensure the interests of shareholders and maintain the transparency of capital market information.

With the problems mentioned above, it is vital to conduct research in order to develop solutions to assist listed companies on the Vietnamese stock market in overcoming the delay in the release of financial statements. Furthermore, a good corporate governance mechanism will act as an excellent monitoring mechanism as well as a valuable measure in the timely disclosure of financial statements, leading to the enhancement of financial statement disclosure quality (Beekes \& Brown, 2006).

This study was conducted to determine the factors affecting the timeliness of financial statements from the perspective of company characteristics and corporate governance mechanism. Besides, previous studies have all identified factors affecting the timeliness of financial statements through testing hypotheses based on the p-value. However, the p-value does not indicate the probability of the hypothesis occurring but the probability of the occurrence of the data. Therefore, in this study, we try to contribute a hypothetical deductive method based on Bayesian analysis. The advantage of Bayesian analysis over p-value is that it shows the probability of the hypothesis occurring. To the best of our knowledge, this is the first study to address this issue when investigating the timeliness of financial statements.

\section{Literature Review and Hypothesis Development}

\subsection{Related Concepts}

\subsubsection{Timeliness of financial statements}

The studies of Al-Ajmi (2008), Daoud et al. (2015), Fakhfakh Sakka \& Jarboui (2016) have separated the timeliness of financial statements into two periods to explain it. The first period is the audit period, which is represented by the Audit Report Lag, which is determined as the number of days 
between the end of the fiscal year and the day the auditor signs the audit report. The second period is the period following the audit (interim period), which is determined by the number of days elapsed between the date the auditor signs the audit report and the date the enterprise publishes the financial statements to the public. However, due to various restrictions in accessing and establishing the precise date when companies release their financial statements to the public, the timeliness technique typically utilized by many researchers is based on the time period from which the financial statements are created from the fiscal year's end until the day the auditor signs the audit report.

\subsubsection{Corporate governance mechanism}

According to Hassan (2016), Mahrani \& Soewarno (2018), the corporate governance mechanism is measured through the board of directors' independence, the ownership of the board, and the quality of audit.

The independence of the Board of Directors is expressed through the percentage of independent members of the Board of Directors. This variable is measured by the number of board members outside the company relative to the total number of board members.

Ownership of the Board of Directors is expressed through the percentage of shares owned by the Board of Directors. This variable is measured by dividing the total number of shares owned by the board of directors by the total number of shares outstanding.

Audit quality is measured as a dummy variable that takes the value of 1 if the company chooses an audit company in the Big4 group (including Deloitte, PWC, E\&Y, KPMG), takes the value of o if it chooses an audit company, not in the Big 4 group.

\subsection{Related studies and research hypotheses}

\subsubsection{The impact of corporate governance mechanism on the timeliness of financial statements}

The corporate governance mechanism is expressed through the percentage of independent members of the board of directors. According to Afify (2009), the supervisory function of the Board of Directors will be enhanced when the number of independent members increases. Independent members are expected to provide criticism for inappropriate actions or decisions of management and protect shareholders' interests. The more independent the Board of Directors, the higher the ratio of independent members to the total number of members of the Board of Directors, the higher the shareholder income, and at the same time, the effectiveness of control is greatly enhanced (Siti Norwahida \& Md. Aminul, 2012). The studies of Afify (2009), Daoud et al. (2015) also provide similar results, suggesting that the higher the proportion of independent directors in the board of directors, the more ensure the timeliness of financial statements. In this study, we expect that the independence of the Board of Directors can increase the timeliness of financial statements. Thus, the research hypothesis is:

Hypothesis H1: Board independence has a positive impact on the timeliness of financial statements.

The corporate governance mechanism is reflected in the share ownership ratio of the board of directors. Share ownership is characterized by the percentage of shares that a person holds in the company. Share ownership of the Board of Directors is determined by the total percentage of shares held by the members of the Board of Directors. Previous studies have shown that board ownership of a large number of shares in a company gives them an incentive to improve firm performance (Brickley et al., 1988) as their decisions affect their interests (Booth et al., 2002). At that time, their interests will be closely tied to the interests of the company. They will have no incentive to make decisions that negatively affect the company's performance and the quality of information published in the financial statements. According to Al-Ajmi (2008), the more concentrated the ownership structure, the shorter the time delay for publication of financial statements. Therefore, in this study, 
we propose the following hypothesis:

Hypothesis H2: Board ownership has a positive impact on the timeliness of financial statements.

The corporate governance mechanism is reflected in the quality of the audit. Bajra \& Čadež (2018) found evidence that the frequency of audits is positively correlated with financial reporting quality. At the same time, the study of Owusu-Ansah \& Leventis (2006) showed that companies that have been audited by Big- 5 audit firms before have a shorter time to prepare financial statements. Cunha \& Rodrigues (2018) supplemented these findings with results showing that Portuguese listed companies audited by a Big-4 audit firm have a higher degree of disclosure. Therefore, in this study, we propose the hypothesis:

Hypothesis $\mathrm{H}_{3}$ : Audit quality positively impacts the timeliness of financial statements (If Big-4 auditors audit the company, it will have a positive impact on the timeliness of financial statements).

\subsubsection{The impact of company characteristics on the timeliness of financial statements}

\subsubsection{Company size}

For better performance, a company needs a large number of employees, a strong internal control system, management capacity, and good facilities. This can only be achieved by large-scale companies (Adebayo \& Adebiyi, 2016). Even so, a large company can improve its corporate governance and ensure the timeliness of financial statements. In other words, larger companies won't spend as much time preparing financial statements. Besides, the failure to promptly publish reports will put great pressure on the company, leading to investors making unwanted transactions on their shares (Owusu-Ansah, 2000). However, Soderstrom \& Sun (2007) also pointed out that the timeliness of financial statements will vary between types of companies. Abdelsalam \& El-Masry (2008) suggested no relationship between firm size and financial reporting timeliness. In this study, we hypothesized the following:

Hypothesis $\mathrm{H}_{4}$ : Company size has a positive effect on the timeliness of financial statements

\subsubsection{Profitability}

According to signal theory, a company would disclose financial statements earlier than usual if it is highly profitable in order to attract investors and lenders. The company wants to announce this great news as soon as possible because the profit demonstrates the company's efficiency (Owusu-Ansah, 200o). This news might potentially have an effect on the company's stock price (Adebayo \& Adebiyi, 2016). Besides, the positive impact of profitability on financial reporting timeliness was also found in previous studies (AL-Tahat, 2015; Kamalluarifin, 2016). The above arguments lead us to the hypothesis that companies will disclose financial statements on time when the company's profitability is high. Therefore, the hypothesis is built as follows:

Hypothesis $\mathrm{H}_{5}$ : Profitability has a positive effect on the timeliness of financial statements

\subsubsection{Leverage}

Many studies have shown that when a company has higher financial leverage, it will have to disclose its financial statements more timely to assure creditors that it is solvency (Kamalluarifin, 2016; Nor Izah Ku Ismail \& Chandler, 2004). Efobi \& Okougbo (2014) suggested that a higher level of leverage would positively affect their corporate governance. That's because it will enhance the timeliness of a company's financial statements, and they won't spend too much time preparing the reports. Therefore, we construct the following hypothesis:

Hypothesis H6: The leverage of the company has a positive impact on the timeliness of financial statements 


\subsubsection{Number of subsidiaries}

The number of subsidiaries is one of the company-specific variables. Subsidiaries are more likely to start and complete audits of financial statements more quickly because of the need to consolidate financial statements. Therefore, firms with many subsidiaries will publish their financial statements sooner (Hossain et al., 2014). However, Ashton et al. (1987), Owusu-Ansah (2000) said that for enterprises with many subsidiaries or branches, the preparation of consolidated financial statements and audit reports would take a long time. This leads to a decrease in the timeliness of financial reporting. In this study, the author agrees with the views of Ashton et al. (1987), Owusu-Ansah (2000) as well as based on the agent theory, the hypothesis is given as follows:

Hypothesis $\mathrm{H}_{7}$ : The number of subsidiaries has a negative impact on the timeliness of financial statements

\section{Methodology}

\subsection{Research model}

To assess the impact of corporate governance mechanism, company characteristics on the timeliness of financial statements in companies listed on the Vietnam stock market, we build the model based on the studies of Al-Ajmi (2008), Bajra \& Čadež (2018), Cunha \& Rodrigues (2018), Daoud et al. (2015), Hassan (2016), Mahrani \& Soewarno (2018) as follows: TFR $i t=\beta_{0}+\beta_{T F P_{i t-1}} \times T F R_{i t-1}+\beta_{S I Z E} \times$ $S I Z E_{i t}+\beta_{R O A} \times R O A_{i t}+\beta_{L E V} \times L E V_{i t}+\beta_{S U B} \times S U B_{i t}+\beta_{N U M} \times N U M_{i t}+\beta_{O W N} \times O W N_{i t}+\beta_{A U D} \times$ $A U D_{i t}+e_{i t}$

Where $i$ represents the ith company, and $t$ represents the time $t, e_{i t}$ is residual in the model.

Table 1: Summary of variables in the research model

\begin{tabular}{|c|c|c|c|c|c|}
\hline Variable & Symbol & Measure & $\begin{array}{l}\text { The basis of variable } \\
\text { selection }\end{array}$ & $\begin{array}{l}\text { The expected } \\
\text { sign of } \\
\text { coefficients }\end{array}$ & Data sources \\
\hline $\begin{array}{l}\text { Timeliness of } \\
\text { financial } \\
\text { statements }\end{array}$ & $\mathrm{TFR}_{\text {it }}$ & $\begin{array}{l}\text { Timeliness is determined by the number of days between } \\
\text { the end of the financial year and the date on which the } \\
\text { independent audit report is signed. The shorter the audit } \\
\text { period, the better the timeliness of financial statements }\end{array}$ & \begin{tabular}{|l|} 
Adebayo \& Adebiyi \\
(2016), AL-Tahat (2015), \\
Kamalluarifin (2016)
\end{tabular} & & $\begin{array}{l}\text { Financial } \\
\text { statements }\end{array}$ \\
\hline Company size & SIZE $_{\text {it }}$ & The natural logarithm of total assets & $\begin{array}{l}\text { Adebayo \& Adebiyi } \\
(2016)\end{array}$ & - & $\begin{array}{l}\text { Financial } \\
\text { statements }\end{array}$ \\
\hline Profitability & $\mathrm{ROA}_{\text {it }}$ & The ratio of the net return on average total assets & $\begin{array}{l}\text { AL-Tahat (2015), } \\
\text { Kamalluarifin (2016) }\end{array}$ & - & $\begin{array}{l}\text { Financial } \\
\text { statements }\end{array}$ \\
\hline Leverage & $\mathrm{LEV}_{\text {it }}$ & The ratio of the debt on total assets & Efobi \& Okougbo (2014) & - & $\begin{array}{l}\text { Financial } \\
\text { statements }\end{array}$ \\
\hline $\begin{array}{l}\text { Number of } \\
\text { subsidiaries }\end{array}$ & $\mathrm{SUB}_{\text {it }}$ & Number of subsidiaries & Owusu - Ansah (200o) & + & $\begin{array}{l}\text { Financial } \\
\text { statements, } \\
\text { Annual report }\end{array}$ \\
\hline $\begin{array}{l}\text { Board } \\
\text { independence }\end{array}$ & $\mathrm{NUM}_{\mathrm{it}}$ & $\begin{array}{l}\text { Number of members on the board of directors outside } \\
\text { the company compared to the total number of members } \\
\text { of the board of directors }\end{array}$ & Daoud et al. (2015) & - & $\begin{array}{l}\text { Financial } \\
\text { statements, } \\
\text { Annual report }\end{array}$ \\
\hline Board ownership & $\mathrm{OWN}_{\mathrm{it}}$ & $\begin{array}{l}\text { Total number of shares owned by the board of directors } \\
\text { divided by the total number of shares outstanding }\end{array}$ & Al-Ajimi (2008) & - & $\begin{array}{l}\text { Financial } \\
\text { statements, } \\
\text { Annual report }\end{array}$ \\
\hline Audit quality & $\mathrm{AUD}_{\text {it }}$ & $\begin{array}{l}\text { Dummy variable that takes the value of } 1 \text { if the company } \\
\text { chooses an audit company in the Big } 4 \text { group (including } \\
\text { Deloitte, PWC, E\&Y, KPMG), takes the value of o if it } \\
\text { chooses an audit company, not in the Big } 4 \text { group }\end{array}$ & $\begin{array}{l}\text { Bajra \& Čadež (2018), } \\
\text { Cunha \& Rodrigues } \\
(2018)\end{array}$ & - & $\begin{array}{l}\text { Financial } \\
\text { statements }\end{array}$ \\
\hline
\end{tabular}

Source: summaries of the authors

\subsection{Hypothesis testing}

The p-values of regression coefficients in the model were often used in previous studies to make 
inferences regarding research hypotheses. The use of a p-value to test a hypothesis has long been criticized (Wasserstein \& Lazar, 2016). The rationale for this criticism is that the p-value is a conditional probability, indicating the likelihood of the data occurring if the hypothesis is determined to be correct. In other words, the p-value does not provide information regarding the probability of the hypothesis occurring.

In this study, we try to contribute a hypothetical deductive method based on Bayesian analysis. The advantage of Bayesian analysis over p-value is that it shows the probability of the hypothesis occurring.

Bayesian analysis is deduced from the posterior distribution of the coefficients in the model. From the posterior distribution of the coefficients in the model, Bayesian analysis shows the probability of the hypothesis occurring.

The posterior distribution is generated by combining a likelihood function and a prior distribution. A likelihood function gives the estimates of the coefficients from data. A prior distribution provides prior information about the coefficients.

Posterior distribution $\propto$ Likelihood function $\times$ Prior distribution

The posterior distribution is created from Markov chains (Markov chain Monte Carlo - MCMC) with well-known sampling methods such as Metropolis-Hastings and Gibbs. In this study, we employ the Metropolis-Hastings sampling technique with an MCMC sample size of 1000.

However, a problem with Bayesian analysis is that the prior distributions for the model coefficients must be reasonably determined. Besides, MCMCs must achieve convergence. For the first problem, we employ fixed effects, random effects, and feasible generalized least squares methods to find information about the prior distributions for the model coefficients. Specifically, the prior distribution will be used as a normal distribution with the parameters obtained from the best estimation method of the three methods above. For the second problem, we use trace plot, histogram, autocorrelation plot, and density plot to make conclusions about the convergence of MCMCs.

\subsection{Data}

The study uses panel data collected from financial statements and annual reports of 172 Vietnamese companies listed on HOSE and HNX from 2014 to 2020. Specifically, data to calculate variables such as timeliness of financial statements, company size, profitability, leverage, audit quality are taken from companies' financial statements. Meanwhile, data to calculate variables such as the number of subsidiaries, board independence, board ownership are taken from both financial statements and annual reports. Descriptive statistics of the variables in the model are presented in the table below.

Table 2: Descriptive statistics of variables in the model

\begin{tabular}{|c|c|c|c|c|c|}
\hline Variable & Obs & Mean & Std. Dev. & Min & Max \\
\hline TFR & 1203 & 99.57 & 63.88 & 10.00 & 466.00 \\
\hline AUD & 1203 & 0.22 & 0.41 & 0.00 & 1.00 \\
\hline SUB & 1203 & 3.86 & 7.57 & 0.00 & 81.00 \\
\hline NUM & 1203 & 2.65 & 9.56 & 0.00 & 50.00 \\
\hline SIZE & 1203 & 20.37 & 1.62 & 15.93 & 25.46 \\
\hline LEV & 1203 & 35.63 & 51.19 & -234.79 & 1277.09 \\
\hline ROA & 1203 & 5.98 & 8.14 & -103.67 & 79.99 \\
\hline OWN & 1203 & 42.41 & 27.71 & 0.07 & 99.66 \\
\hline
\end{tabular}

Source: Author's calculation results

Besides, Figure 1 shows that the correlation between the variables in the model is quite low. This result shows that multicollinearity will not occur in the model. 


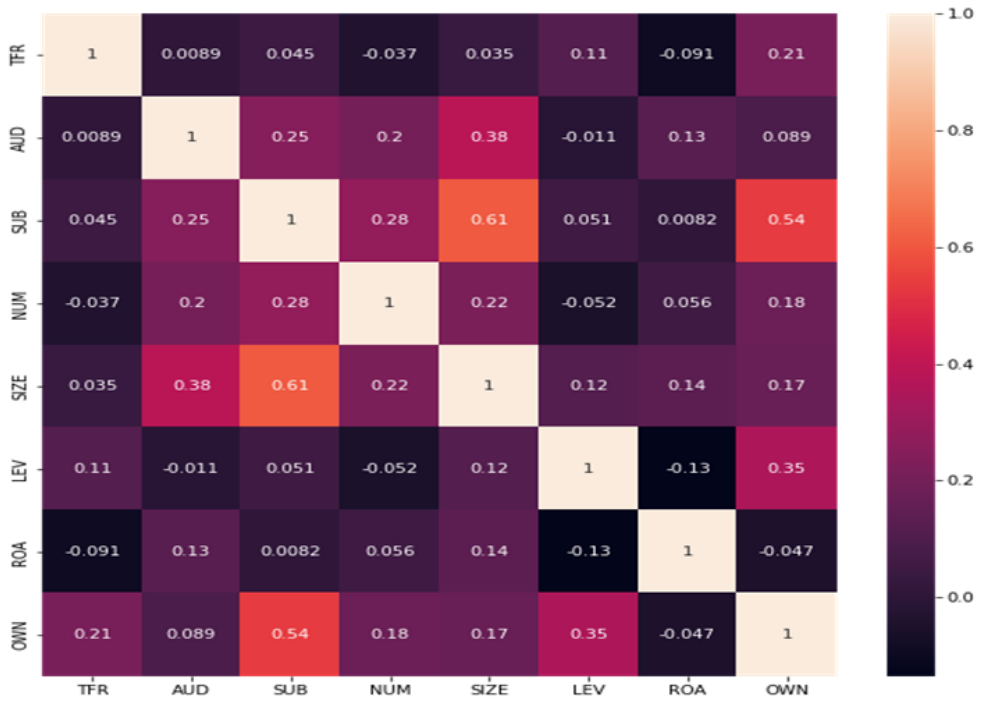

Figure 1: The correlation between the variables in the model

Source: Author's calculation results

\section{Empirical Results}

\subsection{Results of determining the prior distributions}

As mentioned in section 3, we determine the prior distributions of the coefficients by estimating the model according to fixed effects, random effects, and feasible generalized least squares methods. The estimation results are presented in Table 3 below:

Table 3: The results of assessing the impact of corporate governance mechanism, company characteristics on the timeliness of financial statements

\begin{tabular}{|l|c|c|c|}
\hline TFR & $\mathbf{( 1 )}$ & $\mathbf{( 2 )}$ & $\mathbf{3}$ \\
\hline TFR $_{\mathrm{t}-1}$ & $-0.09^{* * *}$ & $0.24^{* * *}$ & $0.05^{*}$ \\
\hline SIZE & $13.69^{* *}$ & $5.53^{* * *}$ & $2.07^{* * *}$ \\
\hline ROA & $-1.35^{* * *}$ & $-0.83^{* * *}$ & $-0.39^{* * *}$ \\
\hline LEV & $-0.29^{* * *}$ & $-0.09^{* *}$ & 0.01 \\
\hline SUB & $-3.46^{* * *}$ & $-1.66^{* * *}$ & $-0.61^{* * *}$ \\
\hline NUM & -0.11 & $-0.36^{*}$ & -0.03 \\
\hline OWN & $0.93^{* * *}$ & $0.37^{* * *}$ & $0.13^{* * *}$ \\
\hline AUD & -13.52 & 1.63 & -0.30 \\
\hline CONS & -183.58 & -42.33 & 38.95 \\
\hline Modified Wald p-value & 0.00 & & \\
\hline Wooldridge p-value & 0.00 & & \\
\hline Hausman p-value & 0.00 & & \\
\hline
\end{tabular}

The results of the model to evaluate the impact of corporate governance mechanism, company characteristics on the

timeliness of financial statements are made with the fixed effects method (model 1), the random effects method. (model 2),

the Feasible Generalized Least Squares method (model 3).

*** statistically significant at the $1 \%$ level.

${ }^{* *}$ statistically significant at the $5 \%$ level

${ }^{*}$ statistically significant at the $10 \%$ level

Source: Author's calculation results 
Hausman's test shows that the model estimated by the fixed effects method is more suitable than the random effects method. However, the Modified Wald test shows that the model estimated by the fixed effects method has heteroskedasticity. Besides, the Wooldridge test also shows that the model estimated by the fixed effect method has the phenomenon of autocorrelation. Therefore, we use the model estimated by the feasible generalized least squares method, which solves heteroskedasticity and autocorrelation.

Thus, Table 3 shows that the prior distributions of the coefficients in the model are determined according to the normal distribution as follows:

$$
\beta_{T F R_{t-1}} \sim \operatorname{Normal}(0.05,0.03) \quad, \quad \beta_{S I Z E} \sim \operatorname{Normal}(2.07,0.74) \quad, \quad \beta_{R O A} \sim \operatorname{Normal}(-0.39,0.1) \quad \text {, }
$$
$\beta_{L E V} \sim \operatorname{Normal}(0.01,0.02) \quad, \quad \beta_{S U B} \sim \operatorname{Normal}(-0.61,0.18) \quad, \quad \beta_{N U M} \sim \operatorname{Normal}(-0.03,0.08)$, $\beta_{\text {OWN }} \sim \operatorname{Normal}(0.13,0.03), \beta_{A U D} \sim \operatorname{Normal}(-0.3,1.78), \beta_{\text {CONS }} \sim \operatorname{Normal}(38.95,14.59)$

\subsection{The convergence of $M C M C$}

The posterior distribution is created from Markov chains (Markov chain Monte Carlo - MCMC) by the Metropolis-Hastings sampling technique. In this study, we employ the Metropolis-Hastings sampling technique with an MCMC sample size of 10oo. The convergence is tested for each MCMC corresponding to each regression coefficient. The result of model estimation by the Bayesian method are presented in the table below.

Table 4: The result of model estimation by Bayesian method

\begin{tabular}{|l|c|c|c|c|c|c|}
\hline TFR & Mean & Std. dev. & MCSE & Median & \multicolumn{2}{|c|}{ [95\% cred. interval] } \\
\hline TFR $_{\mathrm{t}-1}$ & 0.33 & 0.02 & 0.00 & 0.33 & 0.28 & 0.37 \\
\hline SIZE & 1.80 & 0.24 & 0.04 & 1.80 & 1.32 & 2.26 \\
\hline ROA & -1.08 & 0.14 & 0.02 & -1.09 & -1.36 & -0.80 \\
\hline LEV & -0.05 & 0.04 & 0.01 & -0.05 & -0.13 & 0.01 \\
\hline SUB & -1.06 & 0.25 & 0.12 & -1.07 & -1.53 & -0.59 \\
\hline NUM & -0.06 & 0.13 & 0.03 & -0.05 & -0.35 & 0.18 \\
\hline OWN & 0.28 & 0.04 & 0.01 & 0.28 & 0.21 & 0.37 \\
\hline AUD & 5.35 & 0.99 & 0.28 & 5.33 & 3.65 & 7.22 \\
\hline CONS & 28.30 & 2.90 & 0.37 & 28.34 & 22.58 & 34.34 \\
\hline
\end{tabular}

Source: Author's calculation results

Table 4 shows that the posterior mean of the coefficients corresponding to $\mathrm{TFR}_{\mathrm{t}-1}$, SIZE, ROA, LEV, SUB, NUM, OWN, AUD are 0.33, 1.80, -1.08, -0.05, -1.06, -0.06, 0.28, 5.35 respectively. The Bayesian analysis uses $95 \%$ credible intervals instead of $95 \%$ confidence intervals as in frequency analysis. The results show that the $95 \%$ credible intervals of the coefficients corresponding to $\mathrm{TFR}_{\mathrm{t}-1}$, SIZE, OWN, AUD have lower bounds greater than o. Thus, $\mathrm{TFR}_{\mathrm{t}-1}$, SIZE, OWN, AUD will have a positive impact on TFR. Besides, the results also show that the $95 \%$ credible intervals of the coefficients corresponding to ROA, SUB have upper bounds less than o. So, ROA, SUB will have a negative impact on TFR. Particularly, the $95 \%$ credible intervals of the coefficients corresponding to LEV and NUM contain the value $\mathrm{o}$, indicating an unclear impact of these variables on TFR. 

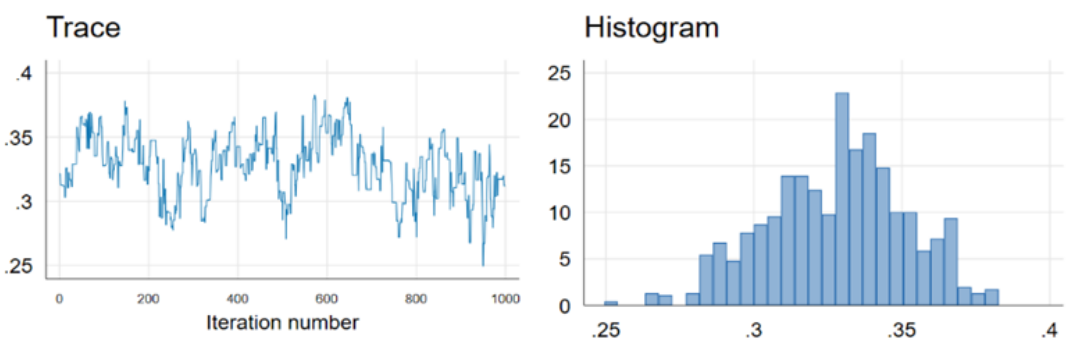

Autocorrelation

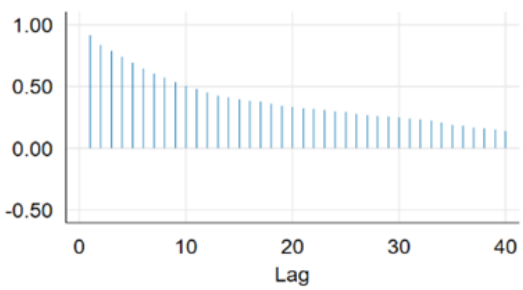

Density

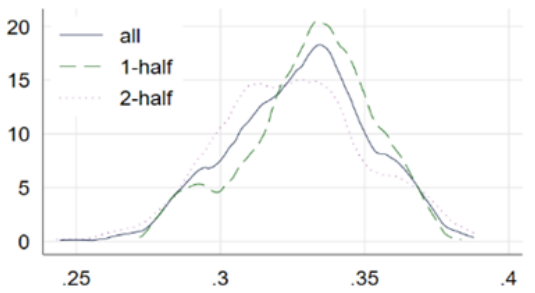

Figure 2: The convergence of MCMC corresponds to the coefficient of $\mathrm{TFR}_{\mathrm{t}-1}$

The MCMC of the coefficient corresponding to $\mathrm{TFR}_{\mathrm{t}-1}$ is convergent, as shown in Figure 2. The Trace plot, in particular, demonstrates that the MCMC is trendless, with the estimated values distributed thickly into a horizontal line that fluctuates around the mean value of 0.33 . The autocorrelation plot illustrates that the correlation is approaching zero. The histogram plot of the MCMC is normally distributed. The density plots of the 1-half, 2-half, and all MCMC have the same form.
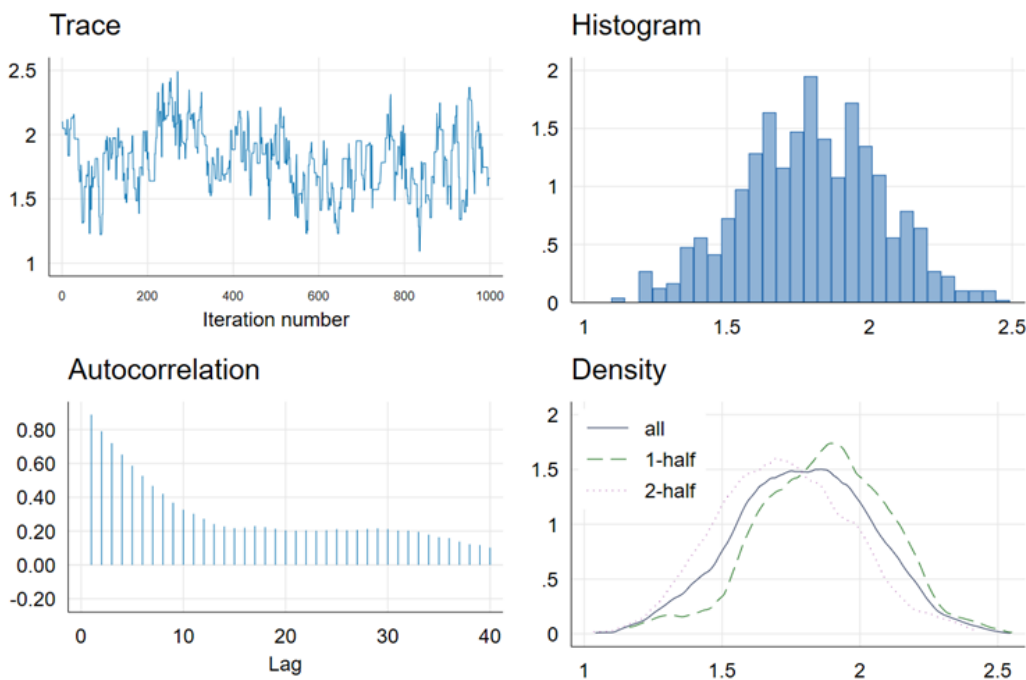

Density

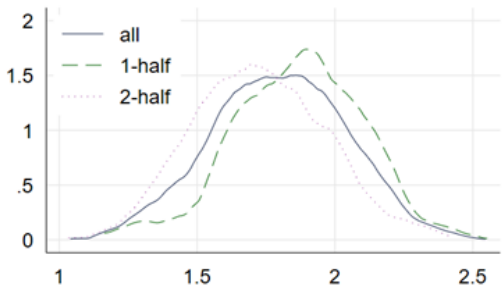

Figure 3: The convergence of MCMC corresponds to the coefficient of SIZE

The MCMC of the coefficient corresponding to SIZE is convergent, as shown in Figure 3. The Trace plot, in particular, demonstrates that the MCMC is trendless, with the estimated values distributed 
thickly into a horizontal line that fluctuates around the mean value of 1.8o. The autocorrelation plot illustrates that the correlation is approaching zero. The histogram plot of the MCMC is normally distributed. The density plots of the 1-half, 2-half, and all MCMC have the same form.
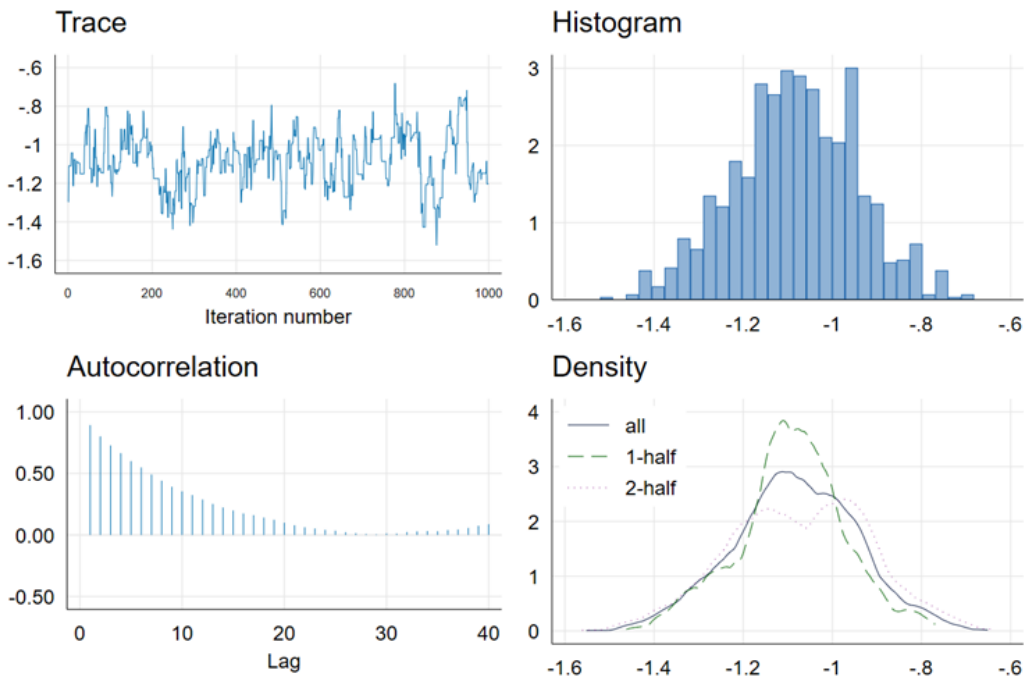

Figure 4: The convergence of MCMC corresponds to the coefficient of ROA

Figure 4 shows that the MCMC of the coefficient corresponding to ROA is convergent. The Trace plot, in particular, demonstrates that the MCMC is trendless, with the estimated values distributed thickly into a horizontal line that fluctuates around the mean value of -1.08 . The autocorrelation plot illustrates that the correlation is approaching zero. The histogram plot of the MCMC is normally distributed. The density plots of the 1-half, 2-half, and all MCMC have the same form.
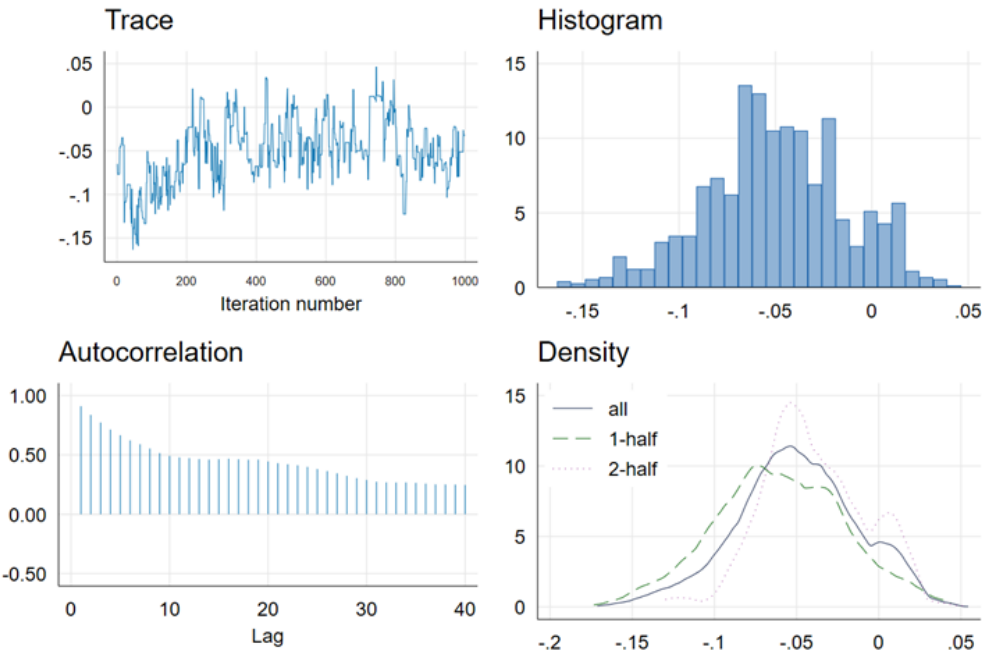

Figure 5: The convergence of MCMC corresponds to the coefficient of LEV 
Figure 5 shows that the MCMC of the coefficient corresponding to LEV is not convergent. The Trace plot, in particular, demonstrates that the MCMC has an uptrend and does not fluctuate around the mean value of -0.05. Similarly, Figure 6 also shows that the MCMC of the coefficient corresponding to SUB is not convergent. The Trace plot, in particular, demonstrates that the MCMC has an uptrend and does not fluctuate around the mean value of -1.06. Besides, the autocorrelation plot illustrates that the correlation is high (more than 0.5). Although the histogram plot of the MCMC is normally distributed, the density plots of the 1-half, 2-half, and all MCMC do not have the same form.
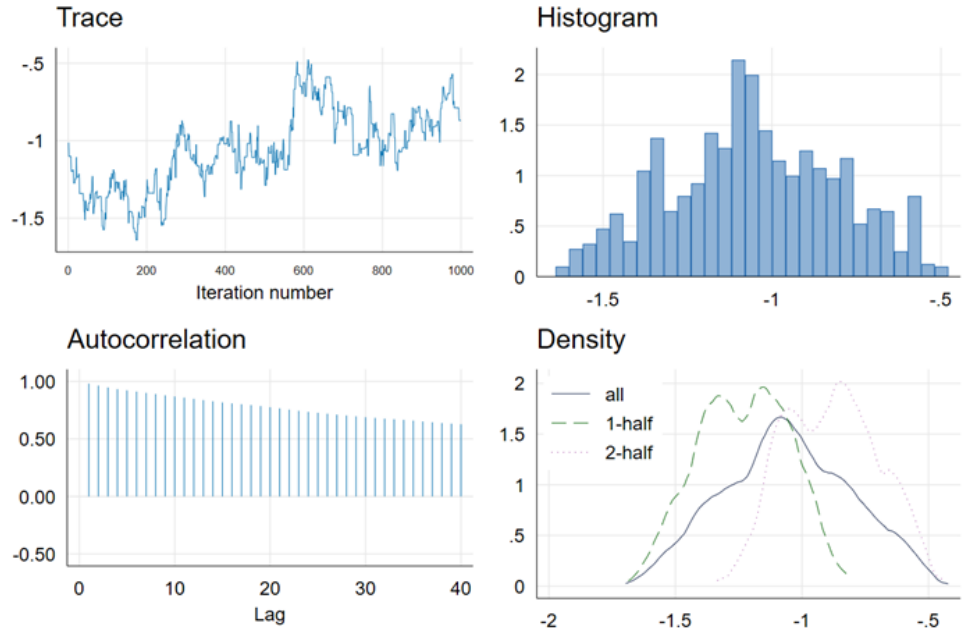

Figure 6: The convergence of MCMC corresponds to the coefficient of SUB

For the corporate governance mechanism variables, the MCMC of the coefficient corresponding to NUM is not convergent, as shown in Figure 7. Specifically, the Trace plot demonstrates that the MCMC has an uptrend and does not fluctuate around the mean value of -o.o6.
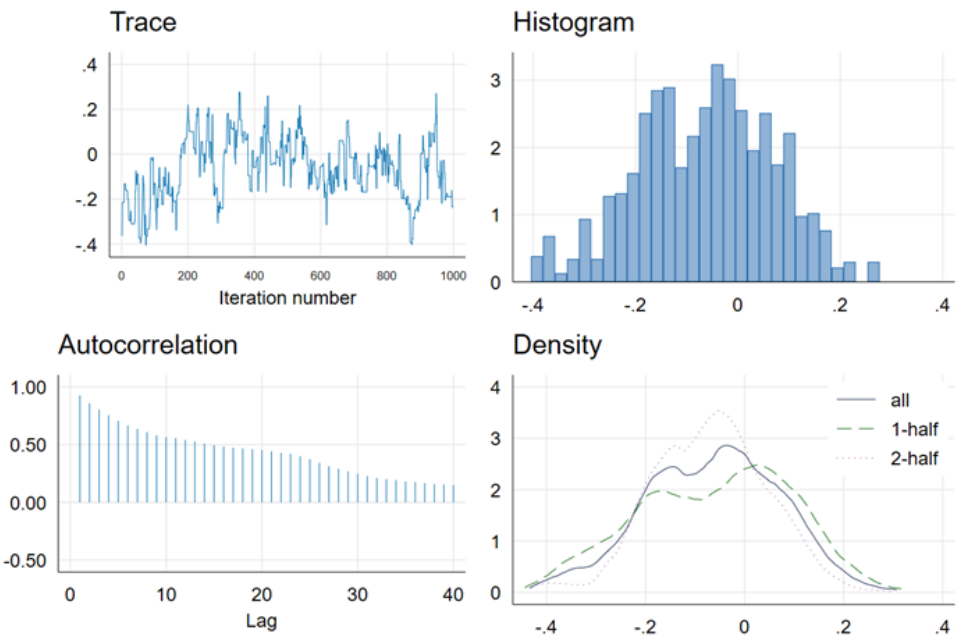

Figure 7: The convergence of MCMC corresponds to the coefficient of NUM 
Figure 8 shows that the MCMC of the coefficient corresponding to OWN is convergent. The Trace plot, in particular, demonstrates that the MCMC is trendless, with the estimated values distributed thickly into a horizontal line that fluctuates around the mean value of -0.28. The autocorrelation plot illustrates that the correlation is approaching zero. The histogram plot of the MCMC is normally distributed. The density plots of the 1-half, 2-half, and all MCMC have the same form.
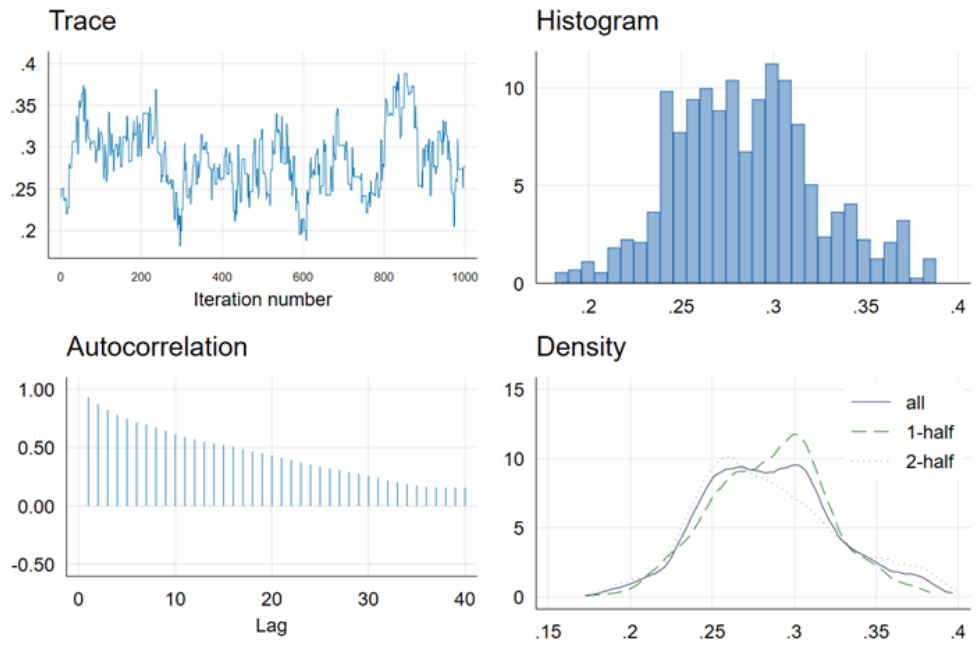

Figure 8: The convergence of MCMC corresponds to the coefficient of OWN

Figure 9 shows that the MCMC of the coefficient corresponding to AUD is convergent. The Trace plot, in particular, demonstrates that the MCMC is trendless, with the estimated values distributed thickly into a horizontal line that fluctuates around the mean value of -5.35 . The autocorrelation plot illustrates that the correlation is approaching zero. The histogram plot of the MCMC is normally distributed. The density plots of the 1-half, 2-half, and all MCMC have the same form.
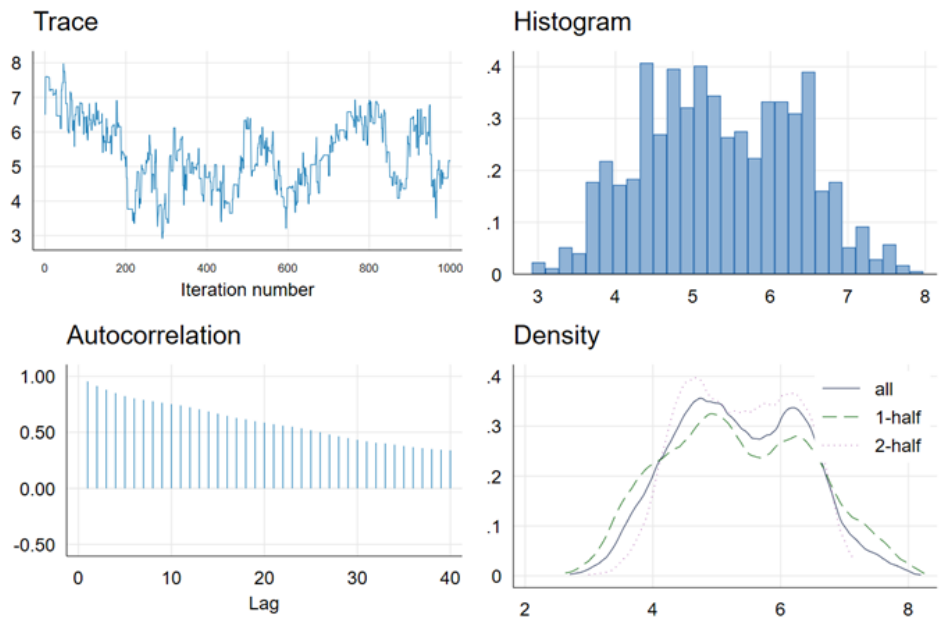

Figure 9: The convergence of MCMC corresponds to the coefficient of AUD 


\subsection{The probability of the hypothesis}

The findings of the Bayesian analysis, as shown above, indicate strong evidence for the impact of $\mathrm{TFR}_{\mathrm{t}-1}$, SIZE, OWN, AUD, and ROA on TFR. As a result, we only compute the probability of the hypotheses $\mathrm{H}_{2}, \mathrm{H}_{3}, \mathrm{H}_{4}, \mathrm{H}_{5}$. The remaining hypotheses are not supported by the results of this study.

Table 5: The probability of the hypothesis

\begin{tabular}{|c|c|c|c|}
\hline Hypothesis & Prob. & Std. dev. & MCSE \\
\hline $\begin{array}{l}\text { Hypothesis H2: Board ownership has a positive impact on the timeliness of } \\
\text { financial statements }\end{array}$ & 0.00 & 0.00 & 0.00 \\
\hline $\begin{array}{l}\text { Hypothesis } \mathrm{H}_{3} \text { : Audit quality positively impacts the timeliness of financial } \\
\text { statements (If Big-4 auditors audit the company, it will have a positive impact on } \\
\text { the timeliness of financial statements) }\end{array}$ & 0.00 & 0.00 & 0.00 \\
\hline $\begin{array}{l}\text { Hypothesis } \mathrm{H}_{4} \text { : Company size has a positive effect on the timeliness of financial } \\
\text { statements }\end{array}$ & 0.00 & 0.00 & 0.00 \\
\hline $\begin{array}{l}\text { Hypothesis } \mathrm{H}_{5} \text { : Profitability has a positive effect on the timeliness of financial } \\
\text { statements }\end{array}$ & 1.00 & 0.00 & 0.00 \\
\hline
\end{tabular}

Source: Author's calculation results

Table 5 shows that the probability of Hypothesis $\mathrm{H}_{2}$ occurring is $\mathrm{o} \%$. As such, board ownership has a negative impact on the timeliness of financial statements. This result is contrary to previous studies of Al-Ajimi (2008), Booth et al. (2002), Brickley et al. (1988). Specifically, in this study, we find that a $1 \%$ increase in board ownership will result in a delay of approximately 28 days in the release of financial statements. To explain this result, we believe that the concentration of stock ownership by the board of directors has limited the functions of the internal audit department and the board of directors and led to delays in the timeliness of financial statements. Listed companies in Vietnam have a high degree of ownership concentration, with the owner playing a large role in the company's management. Corporate governance structures in Vietnamese companies with high board ownership are frequently ineffective as a result of such concentration. Furthermore, in Vietnamese companies, the separation of ownership-management rights is weak, and major shareholders often take the position of head of the board of directors and also hold the position of general director of the company. In developing countries, such a centralized ownership scenario adds to the inefficiencies of the internal audit department and the board of directors (Abdullatif \& Al-Khadash, 2010; Zureigat, 2011).

The probability of Hypothesis $\mathrm{H}_{3}$ is $\mathrm{o} \%$, which means that audit quality negatively affects the timeliness of financial statements. In this study, we find that if the selected audit firm belongs to the Big-4 group, the timeliness of the financial statements will be delayed by about six days. This result is contrary to previous studies of Owusu-Ansah \& Leventis (2006), Bajra \& Čadež (2018), Cunha \& Rodrigues (2018). This is an interesting finding when we look at the audit time of Big-4 auditing firms in a developing country, Vietnam. It is clear that the Big-4 audit firms are careful when assessing companies listed on Vietnam's stock market. The Vietnamese stock market faces a large amount of information asymmetry, moral hazard, and adverse selection due to untimely accounting information. Moreover, the management of Vietnamese companies may have an incentive to commit acts of lack of transparency in financial reporting and tax obligations. Therefore, it is perfectly reasonable to be careful when disclosing audit reports of large and reputable auditing firms.

The probability of Hypothesis $\mathrm{H}_{4}$ is $\mathrm{o} \%$, which means that company size has a negative effect on the timeliness of financial statements. This result contradicts the previous study of Owusu-Ansah (2000). However, it is supported by the study of Soderstrom \& Sun (2007). Large companies are under pressure to release their financial statements on time. However, compared to small companies, the 
financial statements of large companies are more complex. As a result, the audit time will be longer, and overall, the timeliness of the financial statements will be affected.

Finally, Table 5 shows that the probability of Hypothesis $\mathrm{H}_{5}$ occurring is $100 \%$. Therefore, profitability has a positive effect on the timeliness of financial statements. This result is supported by the previous studies of AL-Tahat (2015) and Kamalluarifin (2016). This finding strengthens signal theory, which implies that a company will release its financial statements faster when they are highly profitable. The company wants to announce this great news as soon as possible because the profit demonstrates the company's efficiency (Owusu-Ansah, 200o).

\section{Managerial Implications}

Regarding company characteristics, the results show that company size and profitability have an impact on the timeliness of financial statements. Specifically, company size has a negative effect on the timeliness of financial statements. And profitability has a positive effect on the timeliness of financial statements. Regarding corporate governance mechanisms, the results show that board ownership and audit quality have a negative impact on the timeliness of financial statements.

This study provides a clear view of the impact of business characteristics and corporate governance mechanisms on the timeliness of financial statements of listed companies in Vietnam. This will assist regulators in Vietnam, such as the State Securities Commission of Vietnam, in assessing current listing criteria and reviewing existing ownership structures in companies to ensure financial statements are issued on time. Besides, this study provides awareness and understanding to agencies and stakeholders on whether current corporate governance practices in Vietnamese companies are producing the expected results. Furthermore, this study serves as a basis for policymakers and regulators to develop policies and strategies regarding the timeliness of financial statements.

For users of financial statements, including financial analysts, management, investors, and creditors, this study helps them better understand the factors that influence the timeliness of financial statements. This helps in the validation of financial reporting data and the development of decision-making confidence. The findings may be useful to corporate boards of directors who want to improve the timeliness of financial statements and corporate governance standards in their organizations.

\section{Acknowledgement: Funding}

The study was supported by The Youth Incubator for Science and Technology Programe, managed by Youth Development Science and Technology Center - Ho Chi Minh Communist Youth Union and Department of Science and Technology of Ho Chi Minh City, the contract number is "04/2020/ HĐKHCNT-VU".

\section{References}

Abdelsalam, O., \& El-Masry, A. (2008). The impact of board independence and ownership structure on the timeliness of corporate internet reporting of Irish-listed companies. Managerial Finance, 34(12), 907-918.

Abdullatif, M., \& Al-Khadash, H. A. (2010). Putting Audit Approaches in Context: The Case of Business Risk Audits in Jordan. International Journal of Auditing, 14(1), 1-24. https://doi.org/10.1111/j.1099-1123.2009.00400.X

Adebayo, P. A., \& Adebiyi, W. K. (2016). Effect of firm characteristics on the timeliness of corporate financial reporting: evidence from Nigerian deposit money banks. Undefined. https://www.semanticscholar.org/paper/EFFECT-OF-FIRMCHARACTERISTICS-ON-THE-TIMELINESS-OF-Adebayo-Adebiyi/da956026c8gabogb2ddf5aob49ezıba7f9 uffe84

Anh L.H., Phuoc T., Phuong H.T.N. (2019). The Dependence Between International Crude Oil Price and Vietnam Stock Market: Nonlinear Cointegration Test Approach. In: Kreinovich V., Sriboonchitta S. (eds) Structural Changes and their Econometric Modeling. TES 2019. Studies in Computational Intelligence, vol 808. Springer, Cham. https://doi.org/10.1007/978-3-03o-04263-9_51 
Afify, H. A. E. (2009). Determinants of audit report lag: Does implementing corporate governance have any impact? Empirical evidence from Egypt. Journal of Applied Accounting Research, 10(1), 56-86. https://doi.org/10.1108/o9675420910963397

Al-Ajmi, J. (2008). Audit and reporting delays: Evidence from an emerging market. Advances in Accounting, 24(2), 217-226. https://doi.org/10.1016/j.adiac.2008.08.002

AL-Tahat, S. S. Y. (2015). Company attributes and the timeliness of interim financial reporting in jordan. International Journal of Application or Innovation in Engineering $\mathcal{E}$ Management, 4(3). https://www.ijaiem.org/pabstract.php?vol=Volume4Issue3\&pid=IJAIEM-2015-03-07-8

Ashton, R. H., Willingham, J. J., \& Elliott, R. K. (1987). An Empirical Analysis of Audit Delay. Journal of Accounting Research, 25(2), 275-292. https://doi.org/10.2307/2491018

Bajra, U., \& Čadež, S. (2018). Audit committees and financial reporting quality: The 8th EU Company Law Directive perspective. Economic Systems, 42(1), 151-163. https://doi.org/10.1016/j.ecosys.2017.03.002

Beekes, W., \& Brown, P. (2006). Do Better-Governed Australian Firms Make More Informative Disclosures? Journal of Business Finance \& Accounting, 33(3-4), 422-450. https://doi.org/10.1111/j.1468-5957.2006.oo614.X

Booth, J. R., Cornett, M. M., \& Tehranian, H. (2002). Boards of directors, ownership, and regulation. https://doi.org/10.1016/So378-4266(o1)oo181-9

Brickley, J. A., Lease, R. C., \& Smith, C. W. (1988). Ownership structure and voting on antitakeover amendments. Journal of Financial Economics, 20, 267-291. https://doi.org/10.1016/0304-405X(88)90047-5

Carslaw, C. A. P. N., \& Kaplan, S. E. (1991). An Examination of Audit Delay: Further Evidence from New Zealand. Accounting and Business Research, 22(85), 21-32. https://doi.org/10.1080/o0014788.1991.9729414

Cunha, V., \& Rodrigues, L. L. (2018). Determinants of Structure of Corporate Governance Disclosure in Portugal. https://doi.org/10.7819/RBGN.VoIo.3359

Daoud, K. A. A., Ismail, K., \& Lode, N. A. (2015). The Impact of Internal Corporate Governance on the Timeliness of Financial Reports of Jordanian Firms: Evidence using Audit and Management Report Lags. https://doi.org/10.5901/MJSS.2015.V6NiP430

Efobi, U., \& Okougbo, P. (2014). Timeliness of Financial Reporting in Nigeria. South African Journal of Accounting Research, 28(1), 65-77. https://doi.org/10.1080/10291954.2014.11463127

Fakhfakh Sakka, I., \& Jarboui, A. (2016). Audit reports timeliness: Empirical evidence from Tunisia. Cogent Business E Management, 3(1), 119568o. https://doi.org/10.108o/23311975.2016.119568o

Givoly, D., \& Palmon, D. (1982). Timeliness of Annual Earnings Announcements: Some Empirical Evidence. The Accounting Review, 57(3), 486-508.

Hassan, Y. M. (2016). Determinants of audit report lag: Evidence from Palestine. Journal of Accounting in Emerging Economies, 6(1), 13-32. https://doi.org/10.1108/JAEE-05-2013-0024

Hossain, M. F., Shams Adnan, M. A., \& Joarder, A. H. (2014). Shorter variation of standard deviation for small sample. International Journal of Mathematical Education in Science and Technology, 45(2), 311-316. https://doi.org/10.1080/0020739X.2013.822588

Kamalluarifin, W. F. S. W. (2016). The Influence of Corporate Governance and Firm Characteristics on the Timeliness of Corporate Internet Reporting By Top 95 Companies in Malaysia. https://doi.org/10.1016/S22125671(16)0oo20-4

Leventis, S., Weetman, P., \& Caramanis, C. (2005). Determinants of Audit Report Lag: Some Evidence from the Athens Stock Exchange. International Journal of Auditing, 9(1), 45-58. https://doi.org/10.1111/j.10991123.2005.00101.X

Mahrani, M., \& Soewarno, N. (2018). The effect of good corporate governance mechanism and corporate social responsibility on financial performance with earnings management as mediating variable. Asian Journal of Accounting Research, 3(1), 41-6o. https://doi.org/10.1108/AJAR-o6-2018-ooo8

Nor Izah Ku Ismail, K., \& Chandler, R. (2004). The timeliness of quarterly financial reports of companies in Malaysia. Asian Review of Accounting, 12(1), 1-18. https://doi.org/10.1108/ebo6o770

Owusu-Ansah, S. (2000). Timeliness of corporate financial reporting in emerging capital markets: Empirical evidence from the Zimbabwe Stock Exchange. Accounting and Business Research, 30(3), $241-254$. https://doi.org/10.1080/00014788.2000.9728939

Owusu-Ansah, S., \& Leventis, S. (2006). Timeliness of corporate annual financial reporting in Greece. European Accounting Review, 15(2), 273-287. https://doi.org/10.1080/09638180500252078

Siti Norwahida, S., \& Md. Aminul, I. (2012). The determinants of audit timeliness: Evidence from Malaysia. http://dspace.unimap.edu.my:8o/handle/123456789/31740

Soderstrom, N., \& Sun, K. J. (2007). IFRS Adoption and Accounting Quality: A Review. European Accounting Review, 16(4), 675-702. 
Wasserstein, R. L., \& Lazar, N. A. (2016). The ASA Statement on p-Values: Context, Process, and Purpose. The American Statistician, 7o(2), 129-133. https://doi.org/10.1080/00031305.2016.1154108

Zureigat, Q. (2011). The Effect of Ownership Structure on Audit Quality: Evidence from Jordan. Undefined. https://www.semanticscholar.org/paper/The-Effect-of-Ownership-Structure-on-Audit-Quality\%3A-

Zureigat/ec4934ef6cf6f55d6886af45015364a6o1398913 